www.jmscr.igmpublication.org

Impact Factor (SJIF): 6.379

Index Copernicus Value: 71.58

ISSN (e)-2347-176x ISSN (p) 2455-0450

crossrefDOI: https://dx.doi.org/10.18535/jmscr/v6i7.189

Journal Of Medical Science And Clinical Research

\title{
A cross-sectional Study on Knowledge, Attitude and Practice Regarding Dengue \& Preventive Measures practiced in urban slums of central India
}

\author{
Authors \\ Dr Soumitra Sethia ${ }^{1}$, Aditi Veda ${ }^{2}$, Dr Soumya Sethia* ${ }^{3}$, Sanidhya Sethia ${ }^{4}$ \\ ${ }^{1}$ Post Graduate, Community Medicine, Gandhi Medical College, Bhopal \\ ${ }^{2}$ Assistant Professor, Hospital Management, SIAM\&S, Indore \\ ${ }^{3}$ Post Graduate, R.D. Gardi Medical College, Ujjain \\ ${ }^{4}$ Under Graduate Student, Jawaharlal Nehru Medical College (DMIMS) \\ Corresponding Author \\ Dr Soumya Sethia
}

Post Graduate, R.D. Gardi Medical College, Ujjain, MP, India

\begin{abstract}
Background: Dengue is common \& rapidly spreading mosquito-borne viral disease in the world. As there is no vaccine to protect against dengue, great emphasis is placed on control and preventive measures. Our aim is to create the awareness among people about dengue disease.

Objective: To determine knowledge, attitude and practice (KAP) regarding dengue fever in residents of urban slums.
\end{abstract}

Method: A cross sectional study was conducted among 100 willing families residing in randomly selected urban slums of a metro city of central India. This study was conducted between months of May-June 2018 in urban slum of the city.

Result: A total of 319 respondents were successfully inter-viewed out of which $30.72 \%$ (maximum) respondents belonged to the age group of 26-35 years. With regards to the knowledge about dengue 52.98 $\%$ respondent knew that the vector for dengue is a mosquito and $43.57 \%$ respondents knew about breeding places of mosquitoes. Maximum (57.37\%) respondents were relying upon mosquito mats/coils/liquid vaporizer and $34.80 \%$ were used mosquito spray.

Conclusion: Good dengue prevention demands the involvement of the community. Better information is needed to guide dengue prevention programs in their efforts to engage with the community.

Keywords: Dengue fever, KAP study, Dengue prevention, Mosquito control, Central India.

\section{Introduction}

Dengue is common \& rapidly spreading mosquito-borne viral disease in the world. There are four antigenically distinct dengue virus serotypes (DEN-1, DEN-2, DEN-3 and DEN-4). The dengue virus is transmitted by bites of Aedes aegypti and Aedes albopictus mosquito. ${ }^{(1,5-7)}$
There are two main forms of dengue disease, DF and the more severe dengue haemorrhagic fever (DHF). Infection with dengue virus can produce a broad range of clinical manifestations including asymptomatic infection, mild flu-like symptoms $\&$ more severe haemorrhagic fever. After Second World War, dengue has become a global problem 
and is endemic in more than 110 countries. 2.5 billion people, living in tropics and sub-tropics regions are estimated to be at risk of acquiring dengue infections. Estimated that more than 50100 million infections with about 500,000 cases of severe dengue are reported annually. The case fatality rate of DHF and DSS is around 5 to $7 \% .^{(3,4)}$ In India, major epidemics have been reported in the years 1967, 1970, 1982, 1996 and 2003. ${ }^{(8-10)}$ DF treatment entails mainly supportive therapy. In previous studies, significant independent association of male gender with DHF has been observed. A higher mortality rate was however seen in females. A shift in the age distribution of affected individuals has also been noted; children being affected less in later studies. As there is no vaccine to protect against dengue, great emphasis is placed on control and preventive measures. It is unfortunate that no major steps have been taken to promote awareness and precautionary attitude in the community with regards to dengue fever despite the ostensible burden of disease. Our aim is to create the awareness among people about dengue disease.

\section{Objective}

The study was planned with an objective to determine knowledge, attitude and practice (KAP) regarding dengue fever in residents of urban slums.

\section{Methodology}

A cross sectional study was conducted among residents of urban slums of a metro city of central India. This study was conducted between months of May-June 2018 in a randomly selected urban slum of the city. A total of 100 willing families were assessed for their knowledge, attitude and practice (KAP) regarding dengue fever. Data was collected using a pre-design interviewer administered questionnaire. The questionnaire covered the following areas (1). demographic information - age, gender, occupation, education. (2) Knowledge about Dengue-mode of spread, symptoms, breeding place. (3) Attitudes towards
Dengue. (4) Preventive practices against Dengue. (5) Source of information. Informed consent was taken from all the respondents and confidentiality was ensured throughout the study. Data analysis from the questionnaire were coded and entered into a computerized data base.

\section{Results}

A total of 319 respondents were successfully inter-viewed and data so obtained was used for the primary analysis. $30.72 \%$ (maximum) respondents belonged to the age group of 26-35 years, and $6.27 \%$ (minimum) respondents were $>55$ yrs. $52.99 \%$ respondents were male and $42.01 \%$ were female and $31.35 \%$ respondents were high school certificate. The socio-demographic details of the respondents are shown in Table1. With regards to the knowledge about dengue $52.98 \%$ respondent knew that the vector for dengue is a mosquito. Whereas $45.77 \%$ respondents knew that human to human spread occurs in dengue and mainly transmitted by mosquito bites. Table 2 shows the Data revealing the knowledge of cause of dengue, transmission, its symptoms and preventive measure. Regarding knowledge about breeding, $43.57 \%$ respondents knew about breeding places of mosquitoes. About the timing of the mosquito biting habits, $56.58 \%$ respondents indicated that it is day time, while about $38.53 \%$ respondents thought it is at night. The attitudes of the respondents were assessed using a set of questions regarding dengue. $78.99 \%$ respondents strongly agreed and agreed that dengue is a serious illness. Only $47.02 \%$ respondents strongly agreed and agreed that they are at risk of getting dengue. $73.04 \%$ respondents strongly agreed and agreed that DF can be prevented. $76.49 \%$ respondents strongly agreed and agreed about need for treatment and hospitalization for DF. $86.58 \%$ respondents had a consensus that the government has the prime responsibility to control mosquito breeding. Regarding personal protection against mosquito bite, $(80.56 \%)$ were relying upon mosquito nets, $57.37 \%$ respondents were relying upon mosquito mats/coils/liquid vaporizer and 
$34.80 \%$ were used mosquito spray (Table 3). majority of the respondents were relying upon mosquito nets followed by mats/coils/vaporizers and mosquito sprays. Regarding the source of information (Table 4) on DF, $50.16 \%$ came to know about DF through television followed by newspaper (40.13\%) followed by Friends/relatives $(6.27 \%)$.

Table 1: Socio-demographic characteristics of study population

\begin{tabular}{|l|c|c|}
\hline Gender & 185 & $57.99 \%$ \\
\hline Males & 134 & $42.01 \%$ \\
\hline Females & 319 & $100.00 \%$ \\
\hline Total & 18 & $5.64 \%$ \\
\hline Occupation & 35 & $10.97 \%$ \\
\hline Government employee & 17 & $5.33 \%$ \\
\hline Non-government employee & 74 & $23.20 \%$ \\
\hline Self employee & 89 & $27.90 \%$ \\
\hline Student & 85 & $26.65 \%$ \\
\hline House wife & 1 & $0.31 \%$ \\
\hline Retired & 319 & $100.00 \%$ \\
\hline Unemployed & 53 & $23.51 \%$ \\
\hline Total & 0 & 0 \\
\hline Level of education & 40 & $12.54 \%$ \\
\hline Illiterate & 100 & $31.35 \%$ \\
\hline No formal education & 51 & $15.99 \%$ \\
\hline Till class 5 & 75 & $23.5 \%$ \\
\hline Till class 10
\end{tabular}

Table-2 Knowledge about Dengue Fever

\begin{tabular}{|l|c|c|c|}
\hline & & Frequency & $\%$ \\
\hline \multirow{2}{*}{ A.What is Dengue } & YES & 306 & $95.92 \%$ \\
\cline { 2 - 4 } & NO & 13 & $4.08 \%$ \\
\hline \multirow{2}{*}{ B. spread of Dengue } & YES & 146 & $45.77 \%$ \\
\cline { 2 - 4 } & NO & 173 & $54.23 \%$ \\
\hline \multirow{2}{*}{ C. Biting time } & YES & 56 & $17.55 \%$ \\
\cline { 2 - 4 } & NO & 263 & $82.45 \%$ \\
\hline \multirow{2}{*}{ D. Breeding place } & YES & 139 & $43.57 \%$ \\
\cline { 2 - 4 } & NO & 180 & $56.43 \%$ \\
\hline \multirow{2}{*}{ E.Symptoms } & YES & 103 & $32.29 \%$ \\
\cline { 2 - 4 } & NO & 216 & $67.71 \%$ \\
\hline \multirow{2}{*}{ F. Treatment } & YES & 133 & $41.69 \%$ \\
\cline { 2 - 4 } & NO & 186 & $58.31 \%$ \\
\hline \multirow{2}{*}{$\begin{array}{l}\text { G. Preventive } \\
\text { measure }\end{array}$} & YES & 194 & $60.82 \%$ \\
\cline { 2 - 4 } & NO & 125 & $39.18 \%$ \\
\hline
\end{tabular}

Table-3 Practices to Prevent Dengue Spread

\begin{tabular}{|c|c|c|c|}
\hline & & Frequency & $\%$ \\
\hline \multirow{2}{*}{$\begin{array}{l}\text { A.Use of mosquito } \\
\text { net /coil }\end{array}$} & YES & 257 & $80.56 \%$ \\
\hline & $\mathrm{NO}$ & 62 & $19.44 \%$ \\
\hline \multirow{2}{*}{$\begin{array}{l}\text { B.Cleaning of cooler } \\
\text { / container }\end{array}$} & YES & 247 & $77.43 \%$ \\
\hline & $\mathrm{NO}$ & 72 & $22.57 \%$ \\
\hline \multirow{2}{*}{$\begin{array}{l}\text { C.Cover tank /water } \\
\text { container }\end{array}$} & YES & 225 & $70.53 \%$ \\
\hline & $\mathrm{NO}$ & 94 & $29.47 \%$ \\
\hline \multirow{2}{*}{$\begin{array}{l}\text { D.Use of liquid } \\
\text { vapouriser / cream } \\
\text { /spray }\end{array}$} & YES & 183 & $57.37 \%$ \\
\hline & $\mathrm{NO}$ & 136 & $42.63 \%$ \\
\hline \multirow{2}{*}{$\begin{array}{l}\text { E.Spraying } \\
\text { insecticide in the } \\
\text { community }\end{array}$} & YES & 111 & $34.80 \%$ \\
\hline & $\mathrm{NO}$ & 208 & $65.20 \%$ \\
\hline
\end{tabular}

Table-4 Source of information

\begin{tabular}{|l|c|c|}
\hline Name of source & frequency & \% \\
\hline Television & 160 & $50.16 \%$ \\
\hline Newspaper & 128 & $40.13 \%$ \\
\hline Posters & 11 & $3.45 \%$ \\
\hline Others & 20 & $6.27 \%$ \\
\hline Total & 319 & $100.00 \%$ \\
\hline
\end{tabular}

\section{Conclusion}

Good dengue prevention demands the involvement of the community. Better information is needed to guide dengue prevention programs in their efforts to engage with the community. In urban slums there is a lack of depth of knowledge regarding dengue in the community and observation methods revealed that more efforts to be done by community members themselves to prevent the spread of Aedes mosquitoes. Fortunately, the majority of the community believes they need more information about dengue. These results will guide future research in this area and help to instruct dengue prevention programs.

\section{Reference}

1. WHO. Dengue and Severe Dengue. Geneva: WHO; 2012 [cited 2013].

2. Balaya S, Paul S, D'lima L, Pavri K. Investigations on an outbreak of dengue in Delhi in 1967. 1969.

3. Ahsan T. Dengue fever: a regular epidemic? J Pak Med Assoc 2008; 58: 1-2.

4. Porter KR, Beckett CG, Kosasih H, Tan RI, Alisjahbana B, et al. Epidemiology of 
dengue and dengue hemorrhagic fever in a cohort of adults living in Bandung, West Java, Indonesia. Am J Trop Med Hyg 2005; 72: 60-6.

5. Winch PJ, Leontsini E, Rigau-Pérez JG, Ruiz-Pérez M, Clark GG, Gubler DJ. Community-based dengue prevention programs in Puerto Rico: impact on knowledge, behavior, and residential mosquito infestation. American journal of tropical medicine and hygiene. 2002;67(4):363-70.

6. Guha-Sapir D, Schimmer B. Dengue fever: new paradigms for a changing epidemiology. Emerg Themes Epidemiol. 2005;2(1):1-10.

7. Egger JR, Ooi EE, Kelly DW, Woolhouse ME, Davies CR, Coleman PG. Reconstructing historical changes in the force of infection of dengue fever in Singapore: implications for surveillance and control. Bulletin of the World Health Organization. 2008;86(3):187-96.

8. Acharya A, Goswami K, Srinath S, Goswami A. Awareness about dengue syndrome and related preventive practices amongst residents of an urban resettlement colony of south Delhi. Journal of vector borne diseases. 2005;42(3):122.

9. Itrat A, Khan A, Javaid S, Kamal M, Khan $\mathrm{H}$, Javed S, et al. Knowledge, Awareness and Practices regarding Dengue fever among the adult population of dengue hit cosmopolitan. Plos One. 2008;3(7):e2620.

10. Hairi F, Ong CHS, Suhaimi A, Tsung TW, bin Anis Ahmad MA, Sundaraj C, et al. A knowledge, attitude and practices (KAP) study on dengue among selected rural communities in the Kuala Kangsar district. Asia-Pacific Journal of Public Health. 2003;15(1):37-43. 